\title{
Comparative effects of corn-based diet and phase-fed cassava- based diet on growth rate, carcass characteristics and lipid profile of meat-type ducks
}

\author{
Saowalak Saree', Chaiyapoom Bunchasak ${ }^{1}$, Choawit Rakangtong ${ }^{1}$, Jessada Sakdee', \\ Nuttawut Krutthai ${ }^{1,2, a}$, and Theerawit Poeikhampha ${ }^{1, *}$
}

\footnotetext{
* Corresponding Author: Theerawit Poeikhampha Tel: +66-0-2579-1120, Fax: +66-0-2579-1120, E-mail: agrtrw@ku.ac.th

'Department of Animal Science, Faculty of Agriculture, Kasetsart University, Bangkok 10900, Thailand

2 Department of Agricultural Technology and Development, Faculty of Agricultural Technology, Chiang Mai Rajabhat University, Chang Mai 50330, Thailand

a These authors contributed equally to this work. Submitted May 11, 2016; Revised Sept 2, 2016; Accepted Sept 18, 2016
}

Objective: This experiment was conducted to evaluate the effects of a corn- or cassava- based diet on the production of meat-type ducks.

Methods: Four hundred day-old ducks were used in this experiment. They were divided into five groups with each group replicated eight times. The ducks fed the corn-based diets served as the control group. The four other groups comprised different treatments, with each one given the cassava-based diet based on phase-feeding. Three treatments were fed the cassava-based diet from 16, 28, and $35 \mathrm{~d}$; respectively up to $42 \mathrm{~d}$ of age and the other group was fed the cassavabased diet from 1 to $42 \mathrm{~d}$ of age.

Results: The results indicated that ducks on either the corn- or cassava-based diets were similar in growth during 1 to $9 \mathrm{~d}$ of age. However, toward 35 to $42 \mathrm{~d}$, the cassava-diet produced a higher weight gain $(\mathrm{p}<0.05)$. The cassava-based diet was better than the corn-based diet at increasing the outer and inner breast weights at 28,35 , or $42 \mathrm{~d}(\mathrm{p}<0.05)$. In contrast, the corn-based diet was better at increasing abdominal fat $(\mathrm{p}<0.05)$. The two diets did not differ in their effects on the serum triglyceride, cholesterol, high-density lipoprotein-cholesterol, low-density lipoproteincholesterol, very-low-density lipoprotein-cholesterol, and liver cholesterol. The corn-based diet, however, caused a highly significantly greater level of liver triglyceride $(\mathrm{p}<0.01)$.

Conclusion: The results of this study suggest that both the cassava- and corn- based diets are similar in their effect on meat-type ducks during the starter stage but toward the finisher stage, the cassava-based diet has a better influence on weight gain and carcass characteristics.

Keywords: Feedstuffs; Cassava; Corn; Ducks; Phase Feeding; Lipid Metabolism

\section{INTRODUCTION}

Cassava is a tropical root crop that is widely cultivated in Thailand. Upon maturity, the tubers are harvested, chopped, dried and milled into a powdery form called tapioca. In its raw form, tapioca is bulky and causes dustiness. Thus, to maximize its utilization, it is normally pelleted before being incorporated into a commercial feed formulation. Pelleted tapioca or cassava has been widely accepted as a feed ingredient because it is highly digestible, has a high caloric content and is believed to be less susceptible to aflatoxin contamination. Both in poultry and ruminant feeding, it is considered a potentially viable energy supplement or even a substitute for corn. Among the limitations of its usage at a high level is its high fiber content, dusty particles, low protein value and poor amino acids profile.

Cassava has also been found to be more resistant to mold invasion, a characteristic that makes it advantageous in duck rearing. Particularly during their first two weeks of age, ducks are very susceptible to mycotoxins which can cause high mortality rates. 
The type of dietary carbohydrate has an influence on the way lipids are formed and distributed within the body of the animals. Carcass fats in turn have a significant effect on the dressed meat appearance that plays an important role in the preference of the buyers. Consumers are more discriminating with regard to the kind and amount of animal fats that they consume because studies have shown a correlation between high fat consumption and coronary diseases. Paul et al [1] have reported that too much animal fats may be involved in the formation of thrombi that can block arterial passages that in turn could trigger ischemia. Waraphan [2] reported that using cassava as the source of energy in poultry feeds can result in the birds having lower levels of lipids and cholesterol in the blood.

The key objective of this study was to determine the effects of a cassava-based diet that was phase-fed to meat-type ducks at different growth stages compared to the influence of a corn-based diet on body weight gain, carcass characteristics and lipid levels in the blood and liver.

\section{MATERIALS AND METHODS}

\section{Experimental animals and management}

This study was conducted at The Animal Research Farm, Department of Animal Science, Faculty of Agriculture, Kasetsart University, Thailand. The experimental animals were kept, maintained and treated in adherence with accepted standards for the humane treatment of animals. A total of 400 day-old male ducks (Cherry Valley strain) were used in this experiment. They were divided into 5 groups with each group replicated 8 times and with each replicate having 10 ducks.

At the start of the feeding trial, the total body weight of each experimental grouping was measured and recorded accordingly. The ducks were then put into compartmentalized structures inside a duck house that was equipped with an evaporative cooling system. All the experimental ducks received the same lighting regimen, vaccination program and routine flock management protocols similar to those practiced in commercial duck farms. Feed and water were made available ad libitum.

\section{Experimental design and diets}

This experiment employed a completely randomized design. Both the corn-based diet (control) and the cassava-based diet (experimental) were formulated in accordance with the established nutritional requirements of the ducks based on their age. Diets were offered in a pellet form. They were fed the starter diet for the first $16 \mathrm{~d}$ of age. Subsequently, they were given the finisher diet from 17 to $42 \mathrm{~d}$ of age.

Proximate analyses of the two diets were conducted using the AOAC [3] protocols. The formulations and nutrient compositions of the corn-based and the cassava-based diets are shown in (Table $1,2)$.

\section{Measurements}

Growth performance: All the birds were individually weighed at the dates corresponding to the phase-feeding schedule of the treatment groups, i.e. at $9,16,28,35$, and $42 \mathrm{~d}$ of age in order to determine each treatment's growth response to both the cornbased and the cassava-based diets. The total feed intakes of both the control and the experimental groups were likewise computed at the end of the experimental period to determine the efficiency of each group's feed conversion ratio (FCR).

Carcass quality and visceral organs: At the end of the experi-

Table 1. Experimental diets based on percentage of components

\begin{tabular}{|c|c|c|c|c|c|c|}
\hline \multirow{2}{*}{ Ingredient } & \multicolumn{2}{|c|}{ Starter period (1-9 d) } & \multicolumn{2}{|c|}{ Grower period (10-16 d) } & \multicolumn{2}{|c|}{ Finisher period (17-42 d) } \\
\hline & Corn & Cassava & Corn & Cassava & Corn & Cassava \\
\hline Corn & 54.68 & - & 60.20 & - & 65.16 & - \\
\hline Cassava & - & 47.03 & - & 51.78 & - & 56.05 \\
\hline Palm oil & 1.18 & 1.52 & 1.05 & 1.43 & 0.27 & 0.67 \\
\hline Soybean meal (48\% CP) & 39.29 & 46.73 & 33.76 & 41.95 & 29.57 & 38.43 \\
\hline L-lysine & 0.19 & 0.06 & 0.17 & 0.02 & 0.18 & 0.02 \\
\hline DL-methionine ${ }^{1)}$ & 0.20 & 0.29 & 0.19 & 0.29 & 0.13 & 0.24 \\
\hline L-threonine & 0.05 & 0.06 & 0.08 & 0.09 & 0.04 & 0.04 \\
\hline MDCP & 2.16 & 2.25 & 2.19 & 2.30 & 2.21 & 2.32 \\
\hline Limestone & 1.40 & 1.17 & 1.43 & 1.17 & 1.45 & 1.17 \\
\hline Salt & 0.18 & 0.18 & 0.18 & 0.18 & 0.18 & 0.18 \\
\hline Premix ${ }^{2)}$ & 0.50 & 0.50 & 0.50 & 0.50 & 0.50 & 0.50 \\
\hline Choline chloride (75\%) & 0.11 & 0.16 & 0.19 & 0.25 & 0.25 & 0.31 \\
\hline Antioxidant & 0.02 & 0.02 & 0.02 & 0.02 & 0.02 & 0.02 \\
\hline Mycotoxin binder & 0.05 & 0.05 & 0.05 & 0.05 & 0.05 & 0.05 \\
\hline Total & 100.00 & 100.00 & 100.00 & 100.00 & 100.00 & 100.00 \\
\hline
\end{tabular}

MDCP, monodicalciumphosphate (P 21\%).

1) Synthetic DL-Methionine was supplied by Sumitomo Chemical, Japan.

2) Premix, provided/kg of diet: vitamin $A$ 11,000 IU, vitamin $D_{3} 5,000 \mathrm{IU}$, vitamin $E 75 \mathrm{IU}$, vitamin $\mathrm{K}_{1} 3 \mathrm{mg}$, vitamin $\mathrm{B}_{1} 3 \mathrm{mg}$, vitamin $\mathrm{B}_{2} 8 \mathrm{mg}$, niacin $60 \mathrm{mg}$, pantothenic acid $15 \mathrm{mg}$, pyridoxine 4 mg, folic acid 2 mg, biotin 0.15 mg, choline 1,600 mg, vitamin B 0.016 mg, Mn 120 mg, Zn 100 mg, Cu 16 mg, Selenium 0.30 mg, I 1.25 mg, Fe 40 mg. 
Table 2. Calculated nutrients composition

\begin{tabular}{|c|c|c|c|c|c|c|}
\hline \multirow{2}{*}{ Ingredient } & \multicolumn{2}{|c|}{ Starter period (1-9 d) } & \multicolumn{2}{|c|}{ Grower period (10-16 d) } & \multicolumn{2}{|c|}{ Finisher period (17-42 d) } \\
\hline & Corn & Cassava & Corn & Cassava & Corn & Cassava \\
\hline Energy (ME, kcal/kg) & 2,850 & 2,850 & 2,900 & 2,900 & 2,900 & 2,900 \\
\hline Protein (\%) & 22.00 & 22.00 & 20.00 & 20.00 & 18.50 & 18.50 \\
\hline Fat $(\%)$ & 3.75 & 2.32 & 3.79 & 2.22 & 3.17 & 1.47 \\
\hline Fiber $(\%)$ & 4.12 & 5.01 & 3.87 & 4.85 & 3.70 & 4.76 \\
\hline Calcium (\%) & 1.00 & 1.00 & 1.00 & 1.00 & 1.00 & 1.00 \\
\hline Total phosphorus (\%) & 0.85 & 0.82 & 0.83 & 0.81 & 0.82 & 0.79 \\
\hline Avail. phosphorus (\%) & 0.50 & 0.50 & 0.50 & 0.50 & 0.50 & 0.50 \\
\hline Salt (\%) & 0.20 & 0.20 & 0.20 & 0.20 & 0.20 & 0.20 \\
\hline Lysine (\%) & 1.35 & 1.35 & 1.20 & 1.20 & 1.10 & 1.10 \\
\hline Methionine+cystine (\%) & 0.90 & 0.90 & 0.84 & 0.84 & 0.75 & 0.75 \\
\hline Methionine (\%) & 0.54 & 0.58 & 0.50 & 0.54 & 0.43 & 0.48 \\
\hline Threonine (\%) & 0.90 & 0.90 & 0.85 & 0.85 & 0.75 & 0.75 \\
\hline Tryptophan (\%) & 0.29 & 0.30 & 0.26 & 0.28 & 0.23 & 0.25 \\
\hline Choline (\%) & 0.15 & 0.15 & 0.15 & 0.15 & 0.15 & 0.15 \\
\hline
\end{tabular}

$\mathrm{ME}$, metabolizable energy for poultry.

mental period, three ducks were randomly selected from each of the 40 compartments. All the chosen ducks were then fasted for 12 hours after which they were killed using the $\mathrm{CO}_{2}$ asphyxiation technique. Slaughtering procedures like bleeding, scalding, plucking, evisceration, viscera and abdominal fat weighing and eviscerated carcass weighing were done according to Cabel et al [4]. The fat surrounding the gizzard was included as a component of the abdominal fat weight. Carcass percentages were determined as a ratio of the carcass weight.

Chemical composition analysis: Eight ducks were randomly picked from the control group and from each of the four treatment groups. They were killed by cutting their jugulars and blood samples were collected. Their livers were extracted for liver lipid determination. The blood samples were allowed to clot and then centrifuged at 3,000 rpm for 10 minutes. The enzymatic colorimetric method (Human Gesllschaft für Biochemica and Diagnostica $\mathrm{GmbH}$, Wiesbaden, Germany) was used to obtain the appropriate concentration $(\mathrm{mg} / \mathrm{dL})$ sufficient for blood lipid analysis. The method of Sutton et al [5] was employed to determine the serum lipid profiles. The liver samples were homogenized and then centrifuged for 1 minute at 20,000 rpm to obtain samples for enzymatic colorimetric method analysis as described earlier.

\section{Data analysis}

Using the repeated-measures analysis of main effects due to treatment and time and their interaction, all the experimental data were subjected to analysis of variance according to Steel and Torrie [6]. Means where significant differences occurred were separated using Duncan's new multiple range test [7]. Statements of significance were based on $\mathrm{p}<0.05$ unless otherwise stated and according to the following model;

$$
\mathrm{Y}_{\mathrm{ij}}=\mu+\mathrm{A}_{\mathrm{i}}+\varepsilon_{\mathrm{ij}}
$$

Where; $Y_{i j}$ is the observed response, $A_{i}$ is the effect of diet and $\varepsilon_{\mathrm{ij}}$ is experimental error; $\varepsilon_{\mathrm{ij}} \sim \mathrm{NID}\left(0, \delta^{2}\right)$.

\section{RESULTS AND DISCUSSION}

\section{Growth performances}

The comparative effects of corn versus cassava as dietary energy sources, where the cassava-based diet was phase-fed at different growth stages, on the growth performance of male Cherry Valley ducks are shown in Table 3. Ducks fed the cassava- based diet for 35 or $42 \mathrm{~d}$ of age significantly increased body weight $(\mathrm{p}<0.05)$. However, due possibly to cassava's higher crude fiber content, this group consumed more feed and thus had a higher FCR. As reported [8,9], diets with a high crude fiber content could affect nutrient digestibility and utilization, thus resulting in increased feed intake. Along the same line, some reported that substituting cassava for broken rice resulted in a similar production performance, but with higher feed intake [2]. Cassava as having good digestibility [10]. Its carbohydrate content is about $92 \%$ [11] and its starch contains about $20 \%$ amylose and $70 \%$ amylopectin [ $[12$, 13]. The results of the current study, as shown in (Table 3), demonstrated that cassava is comparable to corn in providing the energy requirements of growing meat-type ducks.

\section{Carcass quality}

Ducks fed the cassava-based diets from 1 to $28 \mathrm{~d}, 1$ to $35 \mathrm{~d}$, or 1 to $42 \mathrm{~d}$ of age significantly increased $(\mathrm{p}<0.05)$ the inner and outer portions of their breast (Table 4). This may be ascribed to improved digestibility of the carbohydrates in cassava due to gelatinization brought about by the heat during the pelletizing of the feeds [14]. This was further confirmed by [14] who reported that gelatinized starch has a higher degree of digestibility than raw starch. The cassava starch in the animal's intestines is digested easily and quickly [15]. Corn, on the other hand, is digested in the intestine 
Table 3. Comparative effects of corn vs cassava (phase-fed) on growth performance of meat-type ducks

\begin{tabular}{|c|c|c|c|c|c|c|c|c|}
\hline \multirow{2}{*}{ Period (d) } & \multirow{2}{*}{ Item } & \multirow{2}{*}{$\begin{array}{c}\text { Corn-based } \\
\text { diet }\end{array}$} & \multicolumn{4}{|c|}{ Cassava-based diet (d) } & \multirow{2}{*}{$p$-value } & \multirow{2}{*}{ SEN } \\
\hline & & & 16 & 28 & 35 & 42 & & \\
\hline 1 & Initial weight (g/duck) & 53.56 & 53.61 & 53.56 & 53.44 & 53.44 & 0.52 & 0.04 \\
\hline \multirow[t]{4}{*}{1 to 9} & Body weight (g/duck) & $293.85^{B}$ & $320.73^{A}$ & $317.91^{\mathrm{A}}$ & $317.03^{A}$ & $314.72^{A}$ & $<0.01$ & 1.23 \\
\hline & Feed intake (g/duck/d) & 44.13 & 45.28 & 44.99 & 45.13 & 44.24 & 0.55 & 0.27 \\
\hline & $A D G$ & $26.71^{B}$ & $29.67^{\mathrm{A}}$ & $29.35^{\mathrm{A}}$ & $29.29^{A}$ & $29.05^{A}$ & $<0.01$ & 0.21 \\
\hline & FCR & $1.65^{B}$ & $1.53^{\mathrm{A}}$ & $1.53^{\mathrm{A}}$ & $1.54^{\mathrm{A}}$ & $1.52^{\mathrm{A}}$ & $<0.01$ & 0.01 \\
\hline \multirow[t]{4}{*}{1 to 16} & Body weight (g/duck) & $733.82^{\mathrm{B}}$ & $812.50^{A}$ & $795.52^{\mathrm{A}}$ & $797.16^{A}$ & $791.95^{A}$ & $<0.01$ & 3.66 \\
\hline & Feed intake (g/duck/d) & $65.60^{B}$ & $72.15^{\mathrm{A}}$ & $70.54^{A}$ & $70.85^{\mathrm{A}}$ & $71.17^{\mathrm{A}}$ & $<0.01$ & 0.56 \\
\hline & $A D G$ & $42.47^{B}$ & $47.40^{\mathrm{A}}$ & $46.38^{A}$ & $46.52^{A}$ & $46.20^{A}$ & $<0.01$ & 0.34 \\
\hline & FCR & 1.54 & 1.52 & 1.52 & 1.52 & 1.54 & 0.92 & 0.01 \\
\hline \multirow[t]{4}{*}{1 to 28} & Body weight (g/duck) & $1,789.14^{B}$ & $1,882.51^{\mathrm{A}}$ & $1,910.39^{A}$ & $1,931.13^{\mathrm{A}}$ & $1,912.03^{A}$ & $<0.01$ & 8.37 \\
\hline & Feed intake (g/duck/d) & $103.58^{C}$ & $108.91^{B}$ & $112.83^{\mathrm{AB}}$ & $115.22^{\mathrm{A}}$ & $113.31^{A B}$ & $<0.01$ & 0.97 \\
\hline & $A D G$ & $61.99^{B}$ & $65.24^{A}$ & $66.37^{A}$ & $67.08^{A}$ & $66.40^{A}$ & $<0.01$ & 0.48 \\
\hline & FCR & 1.67 & 1.67 & 1.70 & 1.72 & 1.71 & 0.23 & 0.01 \\
\hline \multirow[t]{4}{*}{1 to 35} & Body weight (g/duck) & $2,503.97^{B}$ & $2,604.11^{\mathrm{A}}$ & $2,602.40^{A}$ & $2,665.77^{A}$ & $2,631.87^{A}$ & $<0.01$ & 10.52 \\
\hline & Feed intake (g/duck/d) & $118.08^{C}$ & $125.34^{B}$ & $129.71^{A B}$ & $131.23^{A}$ & $130.05^{\mathrm{AB}}$ & $<0.01$ & 1.07 \\
\hline & $A D G$ & $69.88^{B}$ & $72.80^{A}$ & $72.91^{A}$ & $74.67^{A}$ & $73.72^{\mathrm{A}}$ & $<0.01$ & 0.43 \\
\hline & $\mathrm{FCR}$ & 1.69 & 1.72 & 1.78 & 1.76 & 1.76 & 0.06 & 0.01 \\
\hline \multirow[t]{4}{*}{1 to 42} & Body weight (g/duck) & $3,015.16^{B}$ & $3,068.46^{\mathrm{AB}}$ & $3,075.11^{\mathrm{AB}}$ & $3,125.89^{A}$ & $3,107.60^{A}$ & 0.03 & 11.77 \\
\hline & Feed intake (g/duck/d) & $132.04^{c}$ & $138.35^{B}$ & $142.73^{B}$ & $144.06^{\mathrm{AB}}$ & $149.03^{A}$ & $<0.01$ & 1.27 \\
\hline & $A D G$ & 70.43 & 71.84 & 71.96 & 73.43 & 72.75 & 0.15 & 0.39 \\
\hline & $\mathrm{FCR}$ & $1.90^{\mathrm{A}}$ & $1.93^{\mathrm{AB}}$ & $1.98^{B}$ & $1.96^{\mathrm{BC}}$ & $2.04^{c}$ & $<0.01$ & 0.01 \\
\hline
\end{tabular}

SEM, standard error of the mean; $A D G$, average daily gain; $F C R$, feed conversion ratio.

$A, B, C$ Treatment means with different uppercase superscripts in the same row are highly significantly different $(p<0.01)$.

$a, b, c$ Treatment means with different lowercase superscripts in the same row are significantly different $(p<0.05)$.

continuously but at a slower rate. This difference in the rate of digestion could result in a commensurate difference in the glucose level, that is, the level of blood glucose generated from cassava increases easily. Blood glucose levels have a direct effect on the secretion of insulin that stimulates glucose transport [16] and in the introduction of amino acids into cells to be used for protein synthesis [17]. It is possible that in this experiment, cassava's ability to increase blood glucose at a faster rate contributed to the enhancement of amino acid mobility and protein synthesis which in turn resulted in increased outer and inner breast meat yield.

\section{Blood lipid profiles}

Table 5 shows the effects of the corn-based diet (control) and the phase-fed, cassava-based diets on the serum and liver lipid contents. After $42 \mathrm{~d}$ of feeding, the cassava-fed ducks had serum triglycerides, cholesterol, high-density lipoprotein-cholesterol (HDL-C), low-density lipoprotein-cholesterol (LDL-C), very-lowdensity lipoprotein-cholesterol (VLDL-C) and liver cholesterol levels that were not significantly different from those of the control

Table 4. Percentage effects of different energy source on carcass quality and visceral organs

\begin{tabular}{|c|c|c|c|c|c|c|c|}
\hline \multirow{2}{*}{ Item } & \multirow{2}{*}{ Corn-based diet } & \multicolumn{4}{|c|}{ Cassava-based diet (d) } & \multirow{2}{*}{ p-value } & \multirow{2}{*}{ SEM } \\
\hline & & 16 & 28 & 35 & 42 & & \\
\hline Dressed weight & 87.66 & 88.09 & 88.06 & 88.17 & 87.63 & 0.42 & 0.11 \\
\hline Skin & 16.25 & 15.94 & 15.09 & 15.67 & 15.00 & 0.10 & 0.17 \\
\hline Outer breast & $11.69^{b}$ & $12.29^{\mathrm{ab}}$ & $12.84^{\mathrm{a}}$ & $12.77^{\mathrm{a}}$ & $12.86^{\mathrm{a}}$ & 0.01 & 0.13 \\
\hline Inner breast & $1.74^{\mathrm{B}}$ & $1.83^{\mathrm{B}}$ & $1.87^{\mathrm{AB}}$ & $1.90^{A}$ & $1.94^{\mathrm{A}}$ & $<0.01$ & 0.02 \\
\hline Thigh & 9.02 & 8.9 & 9.12 & 8.92 & 9.18 & 0.17 & 0.04 \\
\hline Drumstick & 7.72 & 7.68 & 7.69 & 7.82 & 7.64 & 0.72 & 0.04 \\
\hline Wing & 11.07 & 11.1 & 11.05 & 11.26 & 11.04 & 0.74 & 0.03 \\
\hline Abdominal fat & $0.84^{a}$ & $0.77^{\mathrm{ab}}$ & $0.69^{\mathrm{ab}}$ & $0.64^{b}$ & $0.62 b$ & 0.02 & 0.02 \\
\hline Liver & 2.56 & 2.55 & 2.57 & 2.67 & 2.83 & 0.12 & 0.04 \\
\hline Gizzard & 3.33 & 3.37 & 3.24 & 3.23 & 3.24 & 0.56 & 0.03 \\
\hline
\end{tabular}

SEM, standard error of the mean.

$A, B, C$ Treatment means with different uppercase superscripts in the same row are highly significantly different $(p<0.01)$.

a,b,c Treatment means with different lowercase superscripts in the same row are significantly different $(p<0.05)$. 
Table 5. Effects (mg/dL) of dietary energy source on chemical composition analysis

\begin{tabular}{|c|c|c|c|c|c|c|c|}
\hline \multirow{2}{*}{ Item } & \multirow{2}{*}{ Corn-based diet } & \multicolumn{4}{|c|}{ Cassava-based diet (d) } & \multirow{2}{*}{ p-value } & \multirow{2}{*}{ SEM } \\
\hline & & 16 & 28 & 35 & 42 & & \\
\hline \multicolumn{8}{|l|}{ Serum lipid profiles } \\
\hline Triglyceride & 84.47 & 75.89 & 68.94 & 69.40 & 77.66 & 0.49 & 3.07 \\
\hline Cholesterol & 160.96 & 169.36 & 164.73 & 167.26 & 169.47 & 0.76 & 2.31 \\
\hline HDL-cholesterol & 95.05 & 109.44 & 98.25 & 95.20 & 109.08 & 0.43 & 3.32 \\
\hline LDL-cholesterol & 53.88 & 67.56 & 61.03 & 60.04 & 62.97 & 0.39 & 2.15 \\
\hline VLDL-cholesterol & 16.89 & 15.18 & 13.79 & 13.01 & 15.53 & 0.34 & 0.64 \\
\hline \multicolumn{8}{|l|}{ Liver lipid profiles } \\
\hline Triglyceride & $155.95^{A}$ & $148.63^{\mathrm{AB}}$ & $129.78^{C}$ & $140.59^{B C}$ & $134.49^{B C}$ & $<0.01$ & 2.45 \\
\hline Cholesterol & 44.04 & 47.07 & 44.35 & 43.55 & 46.17 & 0.38 & 0.65 \\
\hline
\end{tabular}

SEM, standard error of the mean; HDL, high-density lipoprotein; LDL, low-density lipoprotein; VLDL, very-low-density lipoprotein

${ }_{A, B, C}$ Treatment means with different uppercase superscripts in the same row are highly significantly different $(p<0.01)$.

$a, b, c$ Treatment means with different lowercase superscripts in the same row are significantly different $(p<0.05)$.

group.

Between and among animal species, there are important differences in the ability to export triglyceride from the liver as VLDL despite the similarity in the rate of esterification of fatty acids to triglyceride [18]. In poultry, fatty acids are actively synthesized in the liver which secretes VLDL at very high rates [19]. The plasma lipoprotein profile of birds is likewise different from that of mammals. In humans, LDL is the largest component of plasma lipoprotein while in birds; the largest component is HDL [20,21]. The results obtained in this study on the effects of dietary energy sources on the serum and liver lipid profiles are in agreement with those reported by [22].

In the control group, which received the corn-based diet, there was a highly significant $(\mathrm{p}<0.01)$ correlation between the ducks' high abdominal fat weights and the equally high levels of triglyceride in the serum and in the liver. This result agrees with [22] who reported that the development of adipose tissues in birds is a direct function of the triglyceride level.

Triglycerides accumulated in the liver of meat-type ducks contribute to the development of body tissues [23]. In the current study, the experimental ducks fed the cassava-based diet from 1 to 28,1 to 35 , or 1 to $42 \mathrm{~d}$ of age had lesser levels of liver triglyceride compared to the corn-based control group. This difference could be attributed to the higher crude fiber in cassava which possibly affected the carbohydrate metabolism. The same phenomenon could similarly explain the low level of triglyceride in the serum which in turn resulted in less fatty adipose tissues recovered from the treatment groups. Similarly, the ducks that received the cassava-based diet had higher levels of HDL or highdensity lipoprotein but lower levels of low-density lipoprotein or LDL. This impact of the cassava-based diet is important from the consumers' viewpoint because medical studies have demonstrated that the levels of HDL and LDL have significant influence in reducing the risks of developing atherosclerotic plaques.

The results of the current study suggest that cassava has nutritional qualities that are similar to those of corn. Its effects on the growth rate were comparable to those of corn up to the end of the starter stage and were even better as the ducks grew older in the finisher stage. Cassava also proved to be comparable to corn in its effects on the ducks' blood and liver lipid levels and on carcass quality. While feeding cassava could result in a greater amount of feed being consumed and thus, a poorer FCR, this could be balanced by the fact that cost-wise, cassava is usually cheaper than corn. The high fiber content of cassava and its dusty texture, which can limit the level of its inclusion in the diet, can be minimized with the help of pelletizing machines.

\section{CONFLICT OF INTEREST}

We certify that there is no conflict of interest with any financial organization regarding the material discussed in the manuscript.

\section{ACKNOWLEDGMENTS}

The authors gratefully acknowledge Sumitomo Chemical Co., Ltd., of Tokyo, Japan for its generous funding assistance. Sincere appreciation is also conveyed to the Center of Advanced Study for Agriculture and Food, Institute for Advanced Studies, Kasetsart University, Thailand. Profound thanks are expressed to Dr. Resty Collado and the entire staff of the Department of Animal Science, Kasetsart University, Thailand for their valuable suggestions, wise guidance and support throughout this trial.

\section{REFERENCES}

1. Paul AA, Southgate DAT. McCance and Widdowson's the composition of food. 4th ed. London, UK: H.M. Stationery Office; 1978.

2. Waraphan J. Effect of substitution of cassava meal for broken rice in diet on production performance, meat quality and population of microorganism in digestive tract of meat ducks. [master's thesis]. Bangkok, TH: Kasetsart University; 2003.

3. AOAC. Official Methods of Analysis of the Association of Official 
Analytical Chemists. 17th ed. Washington, DC: Association of Official Agriculture Chemists; 2000.

4. Cabel MC, Goodwin TL, Waldroup PW. Reduction in abdominal fat content of broiler chickens by the addition of feather meal to finisher diets. Poult Sci 1987;66:1644-51.

5. Sutton CD, Muir WM, Mitchell GE. Cholesterol metabolism in the laying hen as influenced by dietary cholesterol, caloric intake, and genotype. Poult Sci 1984;63:972-80.

6. Steel RGD, Torrie JH. Principles and Procedures of Statistics in Biological Research. 2nd ed. New York, NY: McGraw-Hill; 1980.

7. Duncan DB. Multiple range and multiple F test. Biometrics 1955;11: $1-42$.

8. Mourão JL, Pinheiro VM, Prates JAM, et al. Effect of dietary dehydrated pasture and citrus pulp on the performance and meat quality of broiler chickens. Poult Sci 2008;87:733-43.

9. González JM, Jiménez-Moreno E, González-Sánchez D, Lázaro R, Mateos GG. Effect of inclusion of oat hulls and sugar beet pulp in the diet on productive performance and digestive traits of broilers from 1 to 42 days of age. Anim Feed Sci Technol 2010;162:37-46.

10. Lira MB, Fernandes E. Brematologia das farinhas de mandioca procizidas no Amazonas. Arq Bras Nutr 1982;18:87-94.

11. Oke OL. Cassava as food in Nigeria. World Rev Nutr Diet 1968;9: 272-93.

12. Johnson RM, Raymond WD. The chemical composition of some tropical food plants IV. Manioc. Trop Sci 1965;7:109-15.

13. Muller Z, Chou KC, Nah KC, Tan TK. Study of nutritive value of tapioca in economic rations for growing-finishing pigs in the tropics. Singapore SG: Food and Agricultural Organization of the United Nations; 1972.
14. David LP, Nulsen PEJ, McNamara BR, et al. A high-resolution study of the hydra a cluster with chandra: comparison of the core mass distribution with theoretical predictions and evidence for feedback in the cooling flow. Astrophys J 2001;557:546-59.

15. Enting H, Veldman A, Verstegen MWA, Van der Aar PJ. The effects of low-density diets on broiler breeder development and nutrient digestibility during the rearing period. Poult Sci 2007;86:720-6.

16. Björck I, Liljeberg H, Östman E. Low glycaemic-index foods. Br J Nutr 2000;83(Suppl 1):S149-55.

17. Fox SI. Human physiology. 5th ed. Dubuque, IA: Wm.C. Brown Publishers; 1996.

18. Grummer RR. Etiology of lipid-related metabolic disorders in periparturient dairy cows. J Dairy Sci 1993;76:3882-96.

19. Pullen DL, Liesman JS, Emer RS. A species comparison of liver slice synthesis and secretion of triacylglycerol from nonesterified fatty acids in media. J Anim Sci 1990;68:1395-9.

20. Chapman MJ. Animal lipoproteins: chemistry, structure, and comparative aspects. J Lipid Res 1980;21:789-852.

21. Hermier D, Forgez P, Chapman MJ. A density gradient study of the lipoprotein and apolipoprotein distribution in the chicken, Gallus domesticus. Biochim Biophys Acta 1985;836:105-18.

22. Hermier D, Guy G, Guillaumin S, et al. Differential channeling of liver lipids in relation to susceptibility to hepatic steatosis in two species of ducks. Comp Biochem Physiol B Biochem Mol Biol 2003;135: 663-75.

23. Lien TF, Jan DF, Chen KL. Lipoprotein profiles and components in Tsaiya ducks under ad libitum feeding and fasting. Comp Biochem Physiol A Mol Integr Physiol 2005;142:325-30. 